IRA-International Journal of Education \&

Multidisciplinary Studies

ISSN 2455-2526; Vol.17, Issue o4 (Q4, 2021)

Pg. no. 203-209.

IRA Academico Research

\title{
Teaching Design of English Picture Book for Primary Schools Based on Performance Culture Teaching Method-Taking the Story Time in Unit 1 of the Third Grade of the PEP Version as an Example
}

\author{
Yuan Dandan (1D) \\ ${ }^{1,2}$ School of Foreign Studies. Yangtze University. Hubei. 434023, P. R. China.
}

Type of Work: Peer Reviewed.

DOI: 10.21013/jems.v17.n4.p1

DOI URL: https://dx.doi.org/10.21013/jems.v17.n4.p1

How to cite this paper:

Dandan, Y. (2021). Teaching Design of English Picture Book for Primary Schools Based on Performance Culture Teaching Method-Taking the Story Time in Unit 1 Of the Third Grade of the PEP Version as an Example. IRA-International Journal of Education \& Multidisciplinary Studies (ISSN 2455-2526), 17(4), 203-209. DOI: https://dx.doi.org/10.21013/jems.v17.n4.p1

(C) IRA Academico Research.

(c) EY-NC This work is licensed under a Creative Commons Attribution-NonCommercial 4.0 International License subject to a proper citation to the publication source of the work.

Disclaimer: The scholarly papers as reviewed and published by IRA Academico Research are the views and opinions of their respective authors and are not the views or opinions of IRA Academico Research. IRA Academico Research disclaims any harm or loss caused due to the published content to any party.

IRA Academico Research is an institutional publisher member of Publishers International Linking Association Inc. (PILA-CrossRef), USA. IRA Academico Research is an institutional signatory to the Budapest Open Access Initiative. Hungary advocating the open access of scientific and scholarly knowledge. IRA Academico Research is a registered content provider under Open Access Initiative Protocol for Metadata Harvesting (OAI-PMH).

The journal is indexed \& included in WorldCat Discovery Service (USA), CrossRef Metadata Search (USA), WorldCat (USA), OCLC (USA), Open J-Gate (India), EZB (Germany) Scilit (Switzerland), Airiti (China), Bielefeld Academic Search Engine (BASE) of Bielefeld University, Germany, PKP Index of Simon Fraser University, Canada.

Yuan Dandan (1)/0000-0002-4756-022X

Yuan Dandan is a postgraduate of QZ206 in the School of Yangtze University. 


\section{ABSTRACT}

The performance culture teaching method was first proposed by the American Sinologist Wu Weike. It is a teaching method to learn a second language through the comprehension and practice of the target language. It focuses on culture and practice. The learner presents the story in a rehearsal manner in the context of the target language culture. Picture book teaching is a popular teaching method for primary school English teachers at this stage. Its novel feature of moving from outside class to classroom makes it an indispensable teaching method in primary school English teaching. This article takes the PEP version of the third grade English textbook as an example for teaching design and integrates the performance culture teaching method with the picture book teaching in the primary school English classroom teaching. The focus of research in teaching design is teaching implementation, that is, the application of performance methods in primary school English classrooms. This teaching design combines picture book teaching and performance culture teaching methods to promote primary school English teaching.

Keywords: performance culture teaching method, picture book teaching, primary school English

The illustrated form of English picture books is in line with the cognitive characteristics of primary school students. Selecting appropriate picture books and applying them to English reading teaching will help stimulate students' reading interest, improve students' reading literacy, and promote the sound development of student's cognition, emotion and personality (Zhang Wenhua, Sun Yuan, 2015). Therefore, with the in-depth study of English teaching, English picture books have gradually entered the teaching materials and classroom. Each unit of the PEP primary school English textbook has a storytime section related to the unit theme. This section is a short picture book or a plot in the picture book story. If language learning is simply learning and memorizing knowledge points, it will be very monotonous and boring without the support of background knowledge and situation. Picture books provide support for English language learning to help students understand knowledge in relatively real and interesting situations. The Performance culture teaching method helps students understand, practice, deduce and apply knowledge on the basis of teachers creating a relatively real situation for students.

Therefore, the teaching mode of the integration of English Picture Book Teaching and Performance culture teaching method is worthy of in-depth discussion.

\section{Performance Culture Teaching Method and English Picture Book Teaching 1.1 Performance Culture Teaching Method}

"Performance culture" teaching method is a second language teaching method with the goal of practicing culture proposed by Wu Weike, a Sinologist at Ohio State University. It regards the learning of the second language as a cultural behavior in the target cultural environment. Learning the second language is to experience and practice this cultural behavior (Zhang Juan, 2014). Performance culture teaching method includes two key words: performance and culture. The English word performance of "physical performance" has many different translations in different Chinese contexts, such as "performance", "performance" and "execution". The word "physical performance" integrates the multi-layer meanings of performance, anthropology, sociology and linguistics. In short, it allows learners to "immerse themselves" and "practice" to learn language and culture (Yu, 2010). The meaning of "culture" has various definitions in different academic fields. In the field of foreign language teaching, it is often superficially equated with diet (such as Chinese dumplings), Festival Traditions (such as the customs of the Spring Festival), handicrafts and art (such as paper cutting, film and calligraphy). The teaching principle of culture defines culture as "how people act"(Walker \& Noda, 2000). 
The performance culture teaching method focuses on performance, which can create scenes for students and create an active classroom atmosphere, which helps to improve teaching efficiency and students' oral expression. Moreover, the teaching method is student-centered in the classroom, which can not only effectively give play to students' subjective initiative, but also mobilize students' enthusiasm.

\subsection{English Picture Book Teaching}

English picture books, also known as English picture books or English children's books, are children's books in European and American countries. They are a kind of reading books supplemented with English text descriptions and have a certain plot, and stories presented by integrating visual and language media. Perry Nodelman believes that picture books are through a large number of coherent pictures and relatively few words (or no words) English picture books were introduced into mainland China from 1999 to 2000. China's basic education curriculum reform began in 2001 and put forward a three-level curriculum management model, so that English picture book teaching began to enter the English classroom of primary schools.

"Picture book teaching" is a series of educational and teaching activities around picture books. Its unique teaching content is to present knowledge in the form of graphics, a small amount of words and stories, and the content is complete and interesting. English picture book teaching can not only improve students' reading interest, learning motivation and language knowledge, but also be conducive to the development of students' emotional attitude and values, because students no longer practice language knowledge simply and mechanically, but understand the situation in the story, use language knowledge, and analyze the psychological changes and emotional characteristics of the characters in the story. English picture books are in line with the cognitive characteristics of primary school students. They can help students understand the world and learn language by means of teaching in fun, so as to avoid the phenomenon of only paying attention to language knowledge and boring learning content.

\section{Teaching Design of Primary School English Picture Books based on Performance Culture Teaching Method}

The Performance culture teaching method uses the theory that practice produces true knowledge to study human second language learning, emphasizes that second language learning is regarded as a cultural behavior in the target cultural environment, and uses performance practice to consolidate knowledge. Therefore, teachers will help students build situations and restore scenes according to the contents and themes of textbooks, Let students use and practice text knowledge in a relatively real target language cultural environment as much as possible. At the same time, picture books in English picture book teaching are presented in the form of a small number of words and graphic stories, which directly provide situations for classroom teaching. The combination of Performance culture teaching method and English picture book teaching can not only help students learn and understand language knowledge, analyze article plot, characters, behavior, motivation and emotional attitude in the context, but also increase double interest and improve students' enthusiasm, learning motivation and reading ability. Therefore, the combination of Performance culture teaching method and English picture book teaching is of great help to English teaching. Below is a teaching case designed by taking story time in Unit1 Hello, grade 3 of people's education edition as an example.

\subsection{Teaching Material}

The teaching content of this course is selected from the story time part of Unit1 Hello, grade 3 of Primary School of people's Education Edition. The content of this part is consistent with the theme of this unit. The main content is about how to say hello and introduce yourself when meeting others for the first time. Its presentation 
form is short dialogue and pictures. As students have not yet received systematic and formal English courses, pictures and short dialogues can not only reduce students' memory burden, but also help students intuitively understand the content of the story and stimulate students' interest in learning.

The text content of the story is:

Zip: Hello!

Zoom: Hi! Who's there?

Zip: Guess!

Zoom: Are you Tutu?

Zip: No! Haha! I'm Zip.

Zoom: Hi, Zip! My name’s Zoom

Zip: Let's play! OK?

Zoom: Great!

\subsection{Teaching Purpose}

The integration of the Performance culture teaching method and English picture book teaching can enable students to understand language knowledge, cultivate cultural awareness and thinking quality from three aspects: environment, characters and story plot. At the environmental level, by observing the pictures in the picture book and the teacher's restoration of the scene, students can recognize visual information, such as time, place, season, weather, objects and so on. Through pictures and scenes, students can intuitively understand the meaning of this information and quickly match it with their mother tongue. At the character level, students observe the characters in the picture book and the students in the performance plot and can identify the detailed information such as the characters' actions, emotions, thoughts and views. When reading the picture book, students can understand the meaning of the characters' actions and views, and when performing, they can deeply understand the characters' emotions and figure out the characters' thinking mode, so as to help students cultivate correct emotional attitudes. In terms of plot, students can cultivate correct cultural awareness and thinking quality by reading picture books and performing the plot to capture plot information. Therefore, understanding plot information not only tests students' understanding of language knowledge, but also cultivates students' ability of discrimination and analysis, and trains students' ability to think quality.

\subsection{Teaching Techniques}

The teaching methods of this course mainly include the following: prop tree, prop flower, prop grass, prop fence, mask, video, PPT, blackboard, textbook, chalk, entries and pictures. PowerPoint, blackboard, textbook and chalk are the necessary tools in teaching. Video can help students concentrate and is also one of the common means of classroom introduction. Entries and pictures help students intuitively understand vocabulary and remove obstacles for students' subsequent learning. Props trees, props flowers, props grass, props fences and masks can simulate the environment of the story for students, not only help students integrate into the situation at that time, but also let students approach the story and feel the emotional changes of the characters in the story.

\subsection{Teaching Implementation}

This class is a reading class, which is mainly divided into four steps: pre-class preparation, pre-reading, while reading and post-reading, as well as the analysis of the implementation purpose of each step.

\section{(1) Preparation before class}

The teacher took out the prepared props, asked several students to help arrange the props trees, flowers, 
grass and fences in the blank space next to the podium, and pasted stickers such as trees, flowers, fences and grass on the walls of the classroom to decorate the classroom. Teachers try their best to use props to restore the scene of the story and help students feel the feelings of the characters in the story more appropriately. Props not only increase the interest of the classroom, but also enable students to perform and figure out the details. For example, when zip hides behind the grass, how does he stand and what kind of emotion does he speak with? Props can help students clearly feel and figure out emotions and details.

\section{(2) Pre-reading activities and their implementation purposes}

After the class bell rings, the teacher and students greet each other and announce the class. In the class, the teacher asks the students what cartoons they like to watch, and then asks the students to watch an English video with two questions. After watching the video, the students answer the question: who is in the video? What are they doing? The video content is the first time that the cartoon protagonist Xiong DA and his good friend Jiji meet and introduce themselves to each other.

Since both the unit theme and the storytime theme are about self-introduction and greeting, teachers playing videos related to the theme can not only lead students into the classroom, but also stimulate students' interest. Bear haunting cartoon is one of the cartoons that primary school students must see in early childhood. The content familiar to students in the animation is a support for students to learn new knowledge and help students complete the transformation of knowledge from unknown to known. Therefore, the cartoons familiar to students can not only make students have any pressure but also introduce students' attention into the classroom.

\section{(3) While-Reading Activities and their Implementation Purpose}

The first step is the main idea of the article. The teacher asks the students to read the full text quickly and predict the main idea of the article. This step can help students grasp the main content of the story as a whole without deviating from the theme of the story. The content of the whole article is written for the theme of the article. If you grasp the theme of the article, you can have a macro grasp of the content of the article. Therefore, the mastery of this step is very important for students.

The second step is vocabulary learning. The teacher asks the students to read the whole text with questions about the environmental level and reminds the students to read the pictures in the story. The question is: what do you notice in the picture? Then the teacher invited two students to answer the questions. Through students' answers, teachers can teach students some new words. For example, students answered flowers, trees, bears, squirrels and names in Chinese. When students said a word, teachers pasted the pictures of animals, animal names, plants and their English entries in the picture books prepared in advance on the blackboard to help students understand the meaning of the words. This session aims to cultivate students' observation ability and solve some vocabulary problems.

The third step is to analyze the details. The teacher takes the students to read the whole story in detail and asks the students to answer questions about the character level. The question is: what's the name of the two animals? What are they doing in these pictures? After the students have answered these two questions, the teacher continues to ask how do you know that? With the students analyzing the details of the story and the emotional changes of the characters in the story, bear zoom is happy from the doubt at the beginning to the smile at the back.

The fourth step is to predict the end of the story. The teacher asks the students to predict the end of the story according to the content of the story. If you are zip/zoom, what will you play? Why? At the same time, the teacher shows the language support to students in the PPT "if I were zip / Zoom may, I will play... With zip/zoom, because...". This activity can help students connect the text with themselves after understanding the 
whole picture and details of the story. Students can not only deepen students' understanding and memory of the contents of the textbook but also improve students' interest in English learning.

The fifth step is to read the full text. The teacher asks the students to read the whole story and help them input the content of the story as a whole.

\section{(4) Post-Reading Activity and its Implementation Purposes}

The post-reading activity is role play. The teacher asked the students to work in pairs and invited three groups of students to take the stage to fully interpret the story of the text of Story Time. Before the students' practice in groups, the teacher asks students to practice with their group members. The teacher puts on a squirrel mask to play zip and asks a student to put on a bear mask to play zoom. Zip hides in the grass and wants to attract the attention of Zoom, and loudly says, "Hello!"Zoom is very puzzled and asks: "Hi! Who's there? "Zip laughed and said," Guess! "Zoom still puzzled:" Are you Tutu? ", Zip firmly said: "No" And then naughty jumped out and said, "Haha! I’m Zip! ". Then the enthusiastic suggestion: "let's play! OK?" Zip happily replied: "Great!".

Post-reading activities mainly reflect the integration of the performance culture teaching method and English picture book teaching. Both teaching methods emphasize the importance of the situation. The performance culture teaching method also emphasizes that performance can help students understand and use daily life knowledge. English picture book teaching directly provides a situation for teaching. Students can deduce the story content in the way of physical performance on the basis of the situation, so as to help students understand and apply knowledge.

\section{Conclusion}

In this study, the author combines English Picture Book Teaching with Performance culture teaching method to improve the interest of English classroom because the illustrated form of English picture book is in line with the cognitive characteristics of primary school students and helps to stimulate students' reading interest and improve students' reading literacy. Performance culture teaching method emphasizes performance and simulates story plot to promote students' cognition Sound development of emotion and personality. The combination of the performance culture teaching method and English picture book teaching can diversify classroom activities and improve students' participation, enthusiasm and teachers' teaching effect.

However, how to expand the performance activities in the Performance culture teaching method? How to combine extracurricular picture books with picture books in teaching materials to help students expand their reading? How to apply the knowledge learned in performance to real life? These problems need to be studied by foreign language education researchers.

\section{References}

[1]. Zhang Wenhua, Sun Yuan. Design of English picture book reading teaching activities in primary schools [J]. Journal of School of foreign languages of Shandong Normal University (Basic English Education), 2015,17 (02): 88-92

[2]. Zhang Juan. Research on the teaching method of "performance culture" in teaching Chinese as a foreign language [D]. Hunan: Hunan University, 2014. Performance culture teaching method: origin and core

[3]. YU L. Performance in performed culture: a student's notes. In: WALKER G. The Pedagogy of Performing Another Culture [G].Columbus, OH: National East Asian Languages Resource Center at the Ohio State University; Wuhan: Hubei Education Press, 2010. 173-185.

[4]. WALKER G, NODA M. Remembering the future: compiling knowledge of another culture. In: 
IRA-International Journal of Education \& Multidisciplinary Studies BIRCKBICHLER D. Reflecting on the Past to Shape the Future [GJ. Lincolnwood, IL: National Textbook Company, 2000.187-212.

[5]. Perry Nodelman: The fun of reading children's Literature, Taipei Tianwei Culture books Co., Ltd., 2000 edition. 